\title{
HOW KANSEI ENGINEERING, KANO AND QFD CAN IMPROVE LOGISTICS SERVICES
}

\author{
Markus Hartono $^{1 *}$, Amelia Santoso ${ }^{1}$, Dina Natalia Prayogo ${ }^{1}$ \\ ${ }^{1}$ Department of Industrial Engineering, Faculty of Engineering, University of Surabaya, \\ Surabaya 60293, Indonesia
}

(Received: January 2017 / Revised: June 2017 / Accepted: October 2017)

\begin{abstract}
In the period of 2004 to 2014 there was a significant growth of employment in the logistics sector in Indonesia. This reflects a rapid rise in the need for logistics activities to support outsourcing. Because there is strong competition in the sector, logistics services should be able to deliver both cognitive and affective customer satisfaction. Studies in logistic services have been mainly focused on service gaps, an aspect related to cognitive satisfaction in customers. Many studies have been conducted to evaluate logistics service quality using SERVQUAL and the Kano model. However, these are insufficient in addressing all aspects of logistics provision. Hence, a deep understanding of customer affective need (known in Japanese as Kansei) is required, to provide competitive advantage by modeling more comprehensive customer experiences based on perceived logistics services. This paper proposes a combined model of Kansei Engineering, Kano, and quality function deployment (QFD), which it is hoped will generate more innovative ideas for improvements related to customer emotional satisfaction and customer delight. A case study in supporting logistics services has been chosen to validate the proposed model, and a survey through face-to-face questionnaires involving 157 customers was carried out. The model was then validated, and through the House of Quality (HoQ) concept, some innovative improvement ideas are proposed. They include the use of apps for order confirmation and cancellation, the integration of Google Maps into the ordering system, preorder booking, and a bilingual feature in the transaction menu. Thus, from a practical implication point of view, it is hoped that this study will provide guidelines to the managers of logistics services companies in capturing, measuring and analyzing customer emotional needs (Kansei), with respect to the service attributes which are highly significant to Kansei aspects.
\end{abstract}

Keywords: Kano; Kansei Engineering; Logistics; QFD; Services

\section{INTRODUCTION}

Customer loyalty will be indirectly affected by perceived service quality because of the impact such quality has on the satisfaction that in turn creates loyal customers. Service quality can be considered as a composite of multiple service attributes categorized as tangible or intangible/subjective (Stefano et al., 2015). The assessment of service quality can be performed by investigating the gap between perceived quality and customer expectation, through a research tool known as SERVQUAL (Parasuraman et al., 1988). SERVQUAL has been used extensively since the 1990s, particularly in the service domain. The common dimensions of service captured by SERVQUAL are tangibles, reliability, responsiveness, assurance and empathy.

\footnotetext{
*Corresponding author's email: markus@staff.ubaya.ac.id, Tel: +62-31-2981392, Fax: +62-31-2981151 Permalink/DOI: https://doi.org/10.14716/ijtech.v8i6.689
} 
One of the emerging service sectors is logistics, especially logistics. According to Chen et al. (2015), this type of service can add great value to customers and companies. There are three principal aspects to logistics services for customers: package pick-up, tracking, and delivery services, and these services may play a critical part in leveraging the effectiveness and efficiency of the physical distribution and online transactions of goods, and even of services (Hsu et al., 2011).

Service experiences start and end with human beings, with the meeting of customer needs at the beginning of the process being completed by customer satisfaction and loyalty at the end. Research exploring human involvement in service encounters is less common that other types of research (Drury, 2003). Both the 'servicescape' and interactions between customers and employees will build service satisfaction. In other words, it is said that processes, activities and interactions are more important in service experiences than are things (Lovelock, 1991; Vargo \& Lusch, 2004). In terms of human-based interactions, service experiences will produce both cognitive and affective satisfaction (Wong, 2004; Hartono \& Tan, 2015).

In obtaining a competitive advantage with respect to customer behavior, those delivering services should put more effort into integrating human factors into service design (Abras et al., 2004). The scope of human factors known as ergonomics covers physical and psychological human behaviors, environments, products, and services (Chen et al., 2015). Inherently, the concept of ergonomics has been significantly extended from its original approach related to physical products into service design. Hence, the service provider needs to understand what customers expect and how they perceive the services they receive (Cook et al., 2002).

Products and services are deemed to be successful when they can produce happiness in customers or users (Norman, 2004). Moreover, it is hoped that emotional satisfaction can go beyond just the usability and functionality of products (Helander \& Khalid, 2006; Hartono \& Raharjo, 2015). In dealing with, capturing and modeling customer emotional needs into service design and development, it is proposed that the concepts of Kansei Engineering (KE) can be employed (Nagamachi, 1995; Schütte, 2005; Hartono \& Tan, 2011). Since the 1970s, Kansei has been the dominant ergonomic-based product design development, aiming to put emotions into its core concept, and later to quantify them into design specifications (Nagamachi, 1995).

According to Chen et al. (2015), KE has been applied to the design of physical products such as architectural interiors and exteriors, consumer goods, mobile phones, and even sports shoes. Recent research on KE has demonstrated its applicability for self-monitoring blood glucose applications (Dewi et al., 2017) and, in the Indonesian context, designing $4 \times 2$-wheel-drive passenger car exteriors (Yogasara \& Valentino, 2017). In general, designers use Kansei terms to represent emotional needs which have been translated into product elements. However, the use of $\mathrm{KE}$ in services is deemed to be limited, but its application into services may cover delivery and installation of internet services (Nishino et al., 1999), hotel services (Hartono \& Tan, 2011), restaurant services (Hartono, 2016a), and logistics services (Chen et al., 2015). One of the advantages of $\mathrm{KE}$ is its ability to show the interactive relationship between design characteristics and emotional responses, thus establishing a quantitative framework.

KE has been applied to logistics services as one of the emerging service types, as shown in research by Chen et al. (2015). Recent research into KE in logistics services has been carried out by exploring the quantitative relationship between the feelings (based on Kansei terms) and design elements in home delivery services. This research has shown that when the most important design elements are connected to critical feelings, improvements can emerge. However, in terms of efficiency, the study by Chen et al. (2015) can be strengthened and extended by incorporating potential quality tools, such as the Kano model and QFD. According to Hartono (2012), the use of the Kano model and QFD in Kansei methodology research may 
provide a formal methodology which accounts for customer emotional needs in service design. Hence, this study of KE integrated with the Kano model and QFD in logistics services is proposed. Kano will help with the screening process to identify which service attributes are categorized as one-dimensional $(\mathrm{O})$ and attractive $(\mathrm{A})$, aspects which are critical to Kansei, while QFD will finalize the weighted, prioritized service attributes to be improved using the House of Quality (HoQ) (Hartono \& Tan, 2011).

Thus, the objective of this study is to develop a conceptual framework applied to logistics services combining KE, Kano and QFD concepts, and to conduct an empirical study of ITbased logistics services to test the applicability of the proposed model. The details of the advantages of this integrative framework compared to the individual methods are summarized in Table 1.

Table 1 Comparison between the individual methods and the proposed integrative framework

\begin{tabular}{|c|c|}
\hline Individual method & Proposed integrative framework \\
\hline $\begin{array}{l}\text { KE is used as a bridge between Kansei and service } \\
\text { experience; it is a methodology to translate customer } \\
\text { emotional feelings into service characteristics. However, } \\
\text { it lacks information about which service attributes are } \\
\text { important and most urgently need to be addressed. }\end{array}$ & $\begin{array}{l}\text { To overcome the defined deficiencies, an } \\
\text { integrative framework combining KE, Kano and }\end{array}$ \\
\hline $\begin{array}{l}\text { The Kano model sorts service performance into three } \\
\text { main categories: attractive (A), one-dimensional (O), } \\
\text { and basic/must-be (M) qualities. However, it lacks } \\
\text { information about which service attributes are sensitive } \\
\text { to particular Kansei. }\end{array}$ & $\begin{array}{l}\text { QFD has been proposed. This framework links } \\
\text { sensitive or urgent customer emotional needs } \\
\text { (known as Kansei) with service attributes } \\
\text { experience, and prioritizes which service attributes } \\
\text { are to be improved, taking into account their impact } \\
\text { on Kansei. }\end{array}$ \\
\hline $\begin{array}{l}\text { QFD translates customer needs into product or service } \\
\text { elements/characteristics. However, it lacks information } \\
\text { on customer needs (for instance, customer emotional } \\
\text { needs/Kansei) and a weighting scale formulation. }\end{array}$ & \\
\hline
\end{tabular}

With regard to the details of the proposed approach shown in Table 1, the expected contribution of this current study, as contrasted to the previous research on Kansei, is that it will complete the broader application of KE in the different setting of logistics services. The use of QFD accompanied by a Pareto diagram is expected to explore and consider more practical solutions based on current best practice improvements.

\section{LITERATURE REVIEW}

\subsection{KE in Services}

Referring to Nagamachi (1995) and Nagamachi and Lokman (2011), research into KE ranges from physical products to customer service (known as Kansei quality management). Essentially, the core benefit gained is the same in whichever sector is reviewed, that is, the focus on starting and ending any process with customer emotional needs. More specifically, research into KE in services has been introduced and applied to hotels (Hartono \& Tan, 2011; Hartono \& Raharjo, 2015), restaurants (Hartono, 2016a), and even to interior design (Llinares \& Page, 2011). By embracing current issues of sustainability, KE has been extended to tackle today's organizational problems. The most recent research on KE, in which a more efficient approach has been addressed, is an extended model of KE, Kano and the Teoriya Resheniya Izobretatelskikh Zadach (TRIZ) intended to solve some potential contradictions in solutions (Hartono, 2016a). KE, then, has been extended to cover sustainability issues relating to environmental, economic, and social elements. In term of the research gap identified, a short 
summary of KE research on services published between 2011 and 2017 is provided in the matrix in Table 2.

Table 2 Recent research on KE applied in services

\begin{tabular}{lccccccc}
\hline \multicolumn{1}{c}{ Author(s) } & \multicolumn{7}{c}{ Concerns, tools, and methods } \\
\cline { 2 - 7 } & General KE & SERVQUAL & Kano & TRIZ & Culture & Sustainability & Logistics \\
\hline Llinares \& Page, 2011 & $\sqrt{ }$ & & $\sqrt{ }$ & & & & \\
Hartono \& Tan, 2011 & $\sqrt{ }$ & $\sqrt{ }$ & $\sqrt{ }$ & & & & \\
Hartono, 2012 & $\sqrt{ }$ & $\sqrt{ }$ & & & & & \\
Rasamoelina et al., 2013 & $\sqrt{ }$ & $\sqrt{ }$ & $\sqrt{ }$ & & $\sqrt{ }$ & \\
Hartono et al., 2013 & $\sqrt{ }$ & $\sqrt{ }$ & $\sqrt{ }$ & & $\sqrt{ }$ & \\
Hartono, 2014 & $\sqrt{ }$ & $\sqrt{ }$ & $\sqrt{ }$ & & $\sqrt{ }$ & & \\
Hartono \& Raharjo, 2015 & $\sqrt{ }$ & $\sqrt{ }$ & $\sqrt{ }$ & $\sqrt{ }$ & $\sqrt{ }$ & & $\sqrt{ }$ \\
Chen et al., 2015 & $\sqrt{ }$ & $\sqrt{ }$ & $\sqrt{ }$ & $\sqrt{ }$ & & & $\sqrt{ }$ \\
Hartono, 2016a & $\sqrt{ }$ & $\sqrt{ }$ & $\sqrt{ }$ & & & & \\
Hartono, 2016b & $\sqrt{ }$ & $\sqrt{ }$ &
\end{tabular}

From Table 1 it can be seen that this current research is positioned where KE may contribute to the field of logistics services (in this case, third party logistics, or 3PL) using general KE methodology integrated with SERVQUAL and the Kano model. The choice of the logistics field is hoped to generate a practical contribution to today's trends in services.

\subsection{The Kano Model in Services}

According to Hartono and Tan (2011), the Kano model is deemed to strengthen KE methodology by providing a guideline of how customers rate their satisfaction with perceived services, either as one-dimensional/linear satisfaction or as attractive/delighted satisfaction (Kano et al., 1984). Such aspects are related to Kansei (Hartono \& Tan, 2011). Onedimensional satisfaction provides a linear relationship between product characteristics fulfillment and satisfaction level, whereas attractive/delighted satisfaction will relate more to latent or unspoken needs. Once this type of need is fulfilled, it can generate unpredicted levels of satisfaction. If they are not met only normal satisfaction will be felt. More specifically, such aspects go beyond usability and satisfaction and it is predicted that delighted customers will have an emotional bonding with a particular service provider.

\subsection{The SERVQUAL Model and Logistics Services}

In this study, the service quality for logistics services is modeled and measured by SERVQUAL (see Parasuraman et al. (1988) for details), which consists of five dimensions (tangibles, reliability, responsiveness, empathy, and assurance). SERVQUAL scales will serve as the measurement instrument of perceived and expected services. Overall, logistics service quality covers comprehensive activities ranging from order receipt to delivery to the customer.

In looking at logistics services, one of the most interesting aspects for research is home delivery services, as has been carried out by Chen et al. (2015). Another interesting type, which is becoming a global trend, is that of the logistics service provider or 3PL. Third party logistics is deemed to occupy a critical position in the supply chain for international and domestic trading. From the customers' point of view, Franceschini and Rafele (2000) state that logistics services can be measured in terms of lead-time, regularity, reliability, flexibility, preciseness, harmfulness and productivity. This current research looks 3PL which can be scaled and customized to customer needs such as the level of demand, and delivery service requirements. It may cover products/goods, personal services, and several other types of service. In other words, 3PL may go beyond logistics to include value-added activities. 


\section{FRAMEWORK DEVELOPMENT AND RESEARCH METHODOLOGY}

\subsection{Framework Development}

Based on the research background and KE research in services, a research framework of KE incorporating Kano and QFD is developed (as shown in Figure 1). The framework starts with the problems faced by a particular logistics services company, and then spans the Kansei terms (as the response variables) and perceived service attribute performance (functioning as the predictor variables). Concurrently, a Kano categorization process is conducted to filter the onedimensional and attractive performance indicators ( $\mathrm{O}$ and $\mathrm{A}$ categories) which are sensitive to Kansei. By generating a linear model the development continued with the calculation of satisfaction scores (see Tan \& Pawitra, 2001), and prioritized improvement for particular service attribute(s) is defined. This process is then completed with investigation into how to generate design specification(s) through the application of the QFD HoQ process.

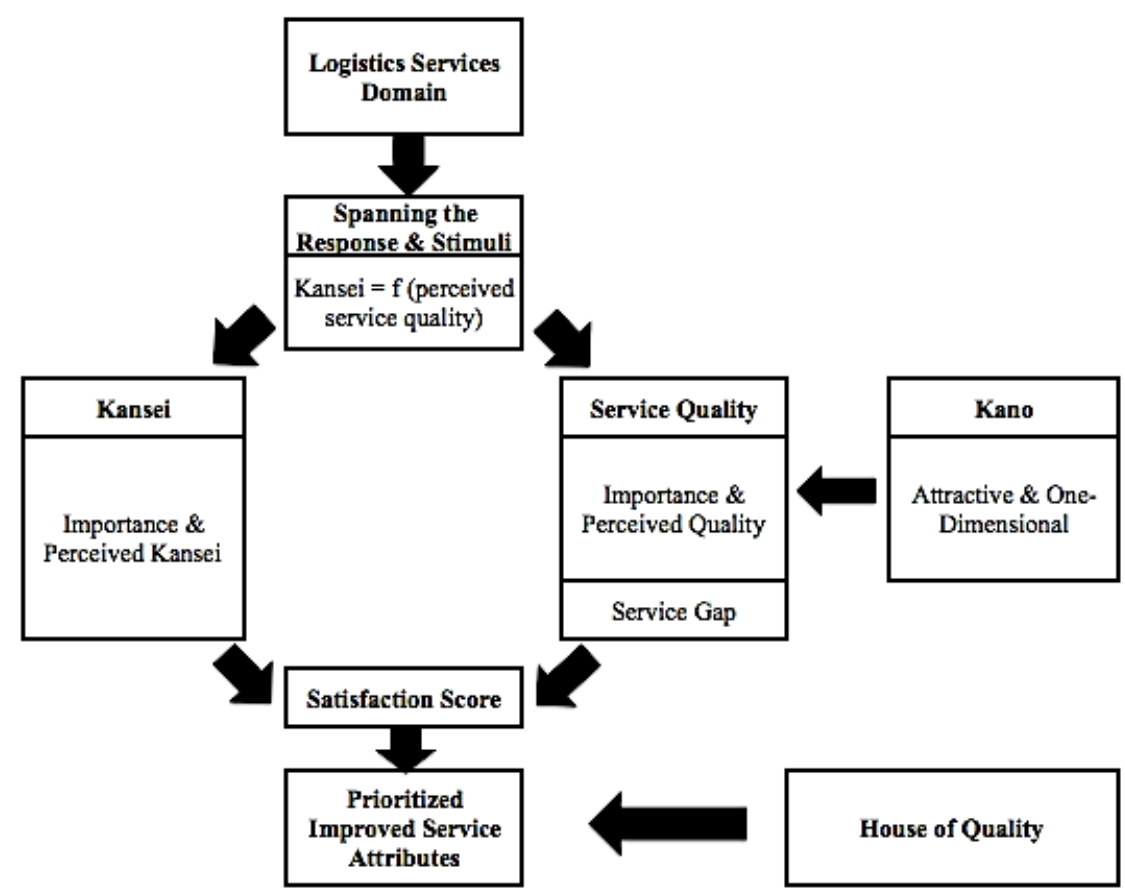

Figure 1 The framework of KE, Kano and QFD for logistics services

\subsection{Research Methodology}

By adopting the methodology proposed by Hartono (2016a; 2016b), this study utilizes a survey approach through a face-to-face questionnaire, convenience sampling plan, and involving a specific target of respondents for particular logistics services. Those who had experienced logistics services from XYZ company at least twice within a year were selected as potential subjects. Items in the questionnaire were devised based on the literature review, interviews with actual users, and personal observation.

\section{CASE STUDY OF IT-BASED APPLICATION LOGISTICS SERVICES}

A case study of IT-based application-supporting logistics services in Surabaya known as XYZ was carried out. XYZ is also known as a hyperlocal transport service that uses motorcycles. The study involved 157 respondents who had those experienced the services of XYZ over the period August-October 2016. Of the respondents 54\% were female and $46 \%$ male, with a majority (55\%) aged from 16 to 25 years, followed by 26-35 years (27\%), 36-45 years (14\%), and 
above 45 years (4\%). Most of the respondents were college students (39\%), followed by professionals $(31 \%)$, entrepreneurs $(17 \%)$, with the remainder being homemakers.

In terms of the discrepancy between the perceived and expected logistics services, the service gap was calculated for each of the logistics service attributes (as shown in Table 3). Then, in order to confirm that the gap was significant, a t-test for comparing two sample means was carried out. The results of the t-test are also provided in Table 3. The results show that, in all service attributes, $\mathrm{H}_{0}$ was rejected. This means that, for all logistics service attributes, the perceived service received was poorer than the expected service. The customers felt that what they had received did not match with what they expected.

Table 3 The statistical test for logistics service gap

\begin{tabular}{|c|c|c|c|c|c|c|c|}
\hline No & Logistics service attributes & Gap* & $\mathrm{t}_{\text {value }}$ & $\mathrm{p}_{\text {value }}$ & $</>$ & $\alpha$ & Remark \\
\hline \multicolumn{8}{|c|}{ Tangibles (T) } \\
\hline 1 & Vehicle type & -0.56 & -7.733 & 0.000 & $<$ & \multirow{10}{*}{0.05} & $\mathrm{H}_{0}$ rejected \\
\hline 2 & Cleanliness of vehicle & -0.86 & -11.852 & 0.000 & $<$ & & $\mathrm{H}_{0}$ rejected \\
\hline 3 & Driver performance & -0.65 & -8.664 & 0.000 & $<$ & & $\mathrm{H}_{0}$ rejected \\
\hline 4 & Completeness of driver's attributes & -0.76 & -9.390 & 0.000 & $<$ & & $\mathrm{H}_{0}$ rejected \\
\hline 5 & Driver rating score & -0.37 & -4.984 & 0.000 & $<$ & & $\mathrm{H}_{0}$ rejected \\
\hline 6 & Web-based application interface & -0.39 & -4.804 & 0.000 & $<$ & & $\mathrm{H}_{0}$ rejected \\
\hline 7 & Cleanliness of helmet for customer & -1.27 & -15.092 & 0.000 & $<$ & & $\mathrm{H}_{0}$ rejected \\
\hline 8 & Provision of mask & -1.25 & -14.352 & 0.000 & $<$ & & $\mathrm{H}_{0}$ rejected \\
\hline 9 & Food receipt & -0.66 & -8.399 & 0.000 & $<$ & & $\mathrm{H}_{0}$ rejected \\
\hline 10 & Appearance of foods ordered & -0.90 & -10.524 & 0.000 & $<$ & & $\mathrm{H}_{0}$ rejected \\
\hline \multicolumn{8}{|c|}{ Empathy (E) } \\
\hline 11 & Provision of apology about any mistakes & -0.71 & -7.853 & 0.000 & $<$ & \multirow{3}{*}{0.05} & $\mathrm{H}_{0}$ rejected \\
\hline 12 & Confirmation of any unavailability of orders & -0.74 & -9.432 & 0.000 & $<$ & & $\mathrm{H}_{0}$ rejected \\
\hline 13 & Confirmation of any cancellations & -0.97 & -12.590 & 0.000 & $<$ & & $\mathrm{H}_{0}$ rejected \\
\hline \multicolumn{8}{|c|}{ Responsiveness (R) } \\
\hline 14 & Friendliness of driver & -0.66 & -8.758 & 0.000 & $<$ & \multirow{5}{*}{0.05} & $\mathrm{H}_{0}$ rejected \\
\hline 15 & Politeness of driver & -0.82 & -11.067 & 0.000 & $<$ & & $\mathrm{H}_{0}$ rejected \\
\hline 16 & Promptness of delivery & -1.01 & -11.221 & 0.000 & $<$ & & $\mathrm{H}_{0}$ rejected \\
\hline 17 & Confirmation of any orders made & -0.47 & -5.543 & 0.000 & $<$ & & $\mathrm{H}_{0}$ rejected \\
\hline 18 & Knowledge of driver of interesting places & -0.99 & -12.256 & 0.000 & $<$ & & $\mathrm{H}_{0}$ rejected \\
\hline \multicolumn{8}{|c|}{ Reliability $(\mathrm{Re})$} \\
\hline 19 & Accuracy of payment & -0.78 & -9.349 & 0.000 & $<$ & \multirow{5}{*}{0.05} & $\mathrm{H}_{0}$ rejected \\
\hline 20 & Accuracy of driver identity & -0.79 & -9.831 & 0.000 & $<$ & & $\mathrm{H}_{0}$ rejected \\
\hline 21 & Accuracy of promotions & -0.55 & -7.361 & 0.000 & $<$ & & $\mathrm{H}_{0}$ rejected \\
\hline 22 & Accuracy of orders & -0.81 & -10.925 & 0.000 & $<$ & & $\mathrm{H}_{0}$ rejected \\
\hline 23 & Safety & -0.87 & -13.978 & 0.000 & $<$ & & $\mathrm{H}_{0}$ rejected \\
\hline \multicolumn{8}{|c|}{ Assurance $(\mathrm{A})$} \\
\hline 24 & Driver traceability & -0.81 & -10.000 & 0.000 & $<$ & \multirow{3}{*}{0.05} & $\mathrm{H}_{0}$ rejected \\
\hline 25 & Warranty for orders & -0.67 & -7.578 & 0.000 & $<$ & & $\mathrm{H}_{0}$ rejected \\
\hline 26 & Privacy for customer & -0.76 & -9.630 & 0.000 & $<$ & & $\mathrm{H}_{0}$ rejected \\
\hline
\end{tabular}

*the difference between perceived and expected service

The perceived logistics services influenced particular Kansei (i.e. aspects of emotional satisfaction). In this study, the following ten Kansei were identified, formalized and measured: helped $($ mean $=4.09)$, trusted $($ mean $=3.93)$, secured $($ mean $=3.91)$, comfortable $($ mean $=$ $3.85)$, innovative $($ mean $=3.83)$, friendly $($ mean $=3.79)$, precise $($ mean $=3.70)$, professional $($ mean $=3.57)$, prompt $($ mean $=3.44)$ and cheap $($ mean $=3.32)$. The distribution of perceived Kansei scores is shown in Figure 2. It shows that Kansei "helped" has the highest perceived score, meaning that, in general, customers felt "helped" when they received logistics services from company XYZ. 


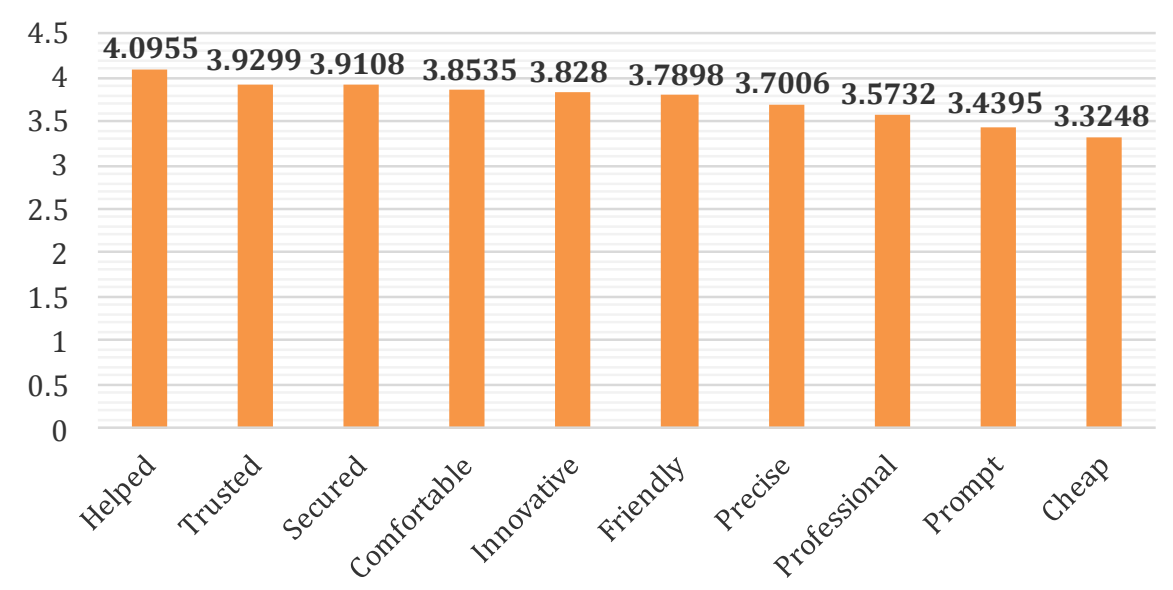

Figure 2 Distribution of perceived Kansei in logistics services

Then, through the Kano categorization process with respect to attractive (A) and onedimensional $(\mathrm{O})$ categories, aspects of the logistics service the Kansei attributes relate to were identified. They were then connected to significant Kansei through a linear model test, to calculate satisfaction scores relating to them. In line with Hartono and Tan (2011), the importance weighting was determined by incorporating the value of the satisfaction score, the Kano weight (see Tan \& Pawitra, 2001), and the Kansei score. The higher the importance weight, the more important the service attribute is. The results are shown in Table 4.

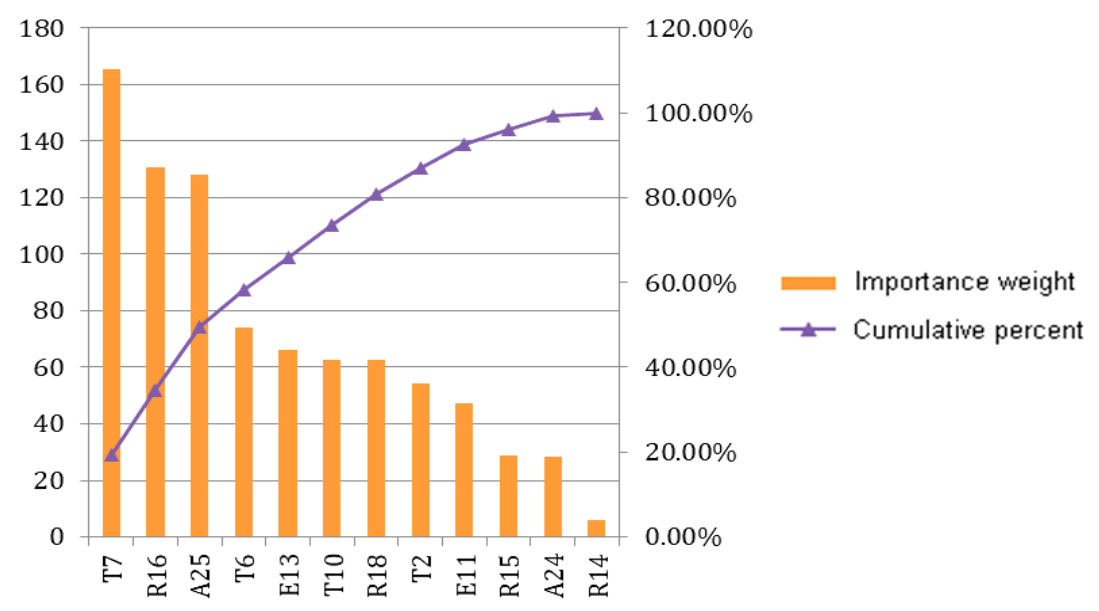

Figure 3 The Pareto chart of logistics service attributes based on importance weight

From the Pareto chart shown in Figure 3 it can be seen that there were seven logistics service attributes deemed to be critical: T7 (cleanliness of helmet for customer), R16 (promptness of delivery), A25 (warranty for orders), T6 (web-based application interface), E13 (confirmation for any cancellations), T10 (appearance of foods ordered) and R18 (knowledge of driver of any interesting places). Using the HoQ method, some related design specifications (known as metrics) were formalized, as shown in Figure 4. It can be seen that the most critical improvement idea was the provision of a modular system for helmets (inside and outside parts) for the customer. 
Table 4 The importance weight of logistics service attributes

\begin{tabular}{|c|c|c|c|c|c|c|c|c|}
\hline No & Code & $\begin{array}{l}\text { Logistics service } \\
\text { attributes }\end{array}$ & $\begin{array}{l}\text { |Satisfaction } \\
\text { score|* }\end{array}$ & & & Kansei sc & & $\begin{array}{c}\text { Importance } \\
\text { weight** }\end{array}$ \\
\hline 1 & $\mathrm{~T} 2$ & Cleanliness of vehicle & 3.47 & $\mathrm{~A}$ & 4 & Secured & 3.91 & 54.27 \\
\hline 2 & $\mathrm{~T} 6$ & $\begin{array}{l}\text { Web-based application } \\
\text { interface }\end{array}$ & 1.58 & A & 4 & $\begin{array}{l}\text { Friendly } \\
\text { Innovative } \\
\text { Helped }\end{array}$ & $\begin{array}{l}3.79 \\
3.83 \\
4.09\end{array}$ & 74.00 \\
\hline 3 & $\mathrm{~T} 7$ & $\begin{array}{l}\text { Cleanliness of helmet } \\
\text { for customer }\end{array}$ & 5.73 & $\mathrm{O}$ & 2 & $\begin{array}{l}\text { Professional } \\
\text { Innovative } \\
\text { Cheap } \\
\text { Precise }\end{array}$ & $\begin{array}{l}3.57 \\
3.83 \\
3.32 \\
3.70 \\
\end{array}$ & 165.25 \\
\hline 4 & $\mathrm{~T} 10$ & $\begin{array}{l}\text { Appearance of foods } \\
\text { ordered }\end{array}$ & 3.84 & A & 4 & Helped & 4.09 & 62.82 \\
\hline 5 & E11 & $\begin{array}{l}\text { Provision of apology for } \\
\text { any mistakes }\end{array}$ & 3.06 & A & 4 & Comfortable & 3.85 & 47.12 \\
\hline 6 & E13 & $\begin{array}{l}\text { Confirmation for any } \\
\text { cancellations }\end{array}$ & 4.16 & $\mathrm{O}$ & 2 & $\begin{array}{l}\text { Helped } \\
\text { Comfortable }\end{array}$ & $\begin{array}{l}4.09 \\
3.85\end{array}$ & 66.07 \\
\hline 7 & R14 & Friendliness of driver & 2.95 & $\mathrm{O}$ & 2 & - & & 5.90 \\
\hline 8 & $\mathrm{R} 15$ & Politeness of driver & 3.69 & $\mathrm{O}$ & 2 & Trusted & 3.93 & 29.00 \\
\hline 9 & $\mathrm{R} 16$ & Promptness of delivery & 4.52 & A & 4 & $\begin{array}{l}\text { Friendly } \\
\text { Prompt }\end{array}$ & $\begin{array}{l}3.79 \\
3.44\end{array}$ & 130.71 \\
\hline 10 & $\mathrm{R} 18$ & $\begin{array}{l}\text { Knowledge of driver of } \\
\text { interesting places }\end{array}$ & 4.24 & $\mathrm{~A}$ & 4 & Precise & 3.70 & 62.75 \\
\hline 11 & A24 & Driver traceability & 3.44 & $\mathrm{O}$ & 2 & Helped & 4.09 & 28.14 \\
\hline 12 & A25 & Warranty for orders & 2.74 & A & 4 & $\begin{array}{l}\text { Trusted } \\
\text { Secured } \\
\text { Comfortable }\end{array}$ & $\begin{array}{l}3.93 \\
3.91 \\
3.85\end{array}$ & 128.12 \\
\hline
\end{tabular}

$* \mid$ satisfaction score $\mid=($ perceived - expected $) x$ importance level of service

**importance weight $=\mid$ satisfaction score $\mid x$ Kano weight $x$ Kansei score 


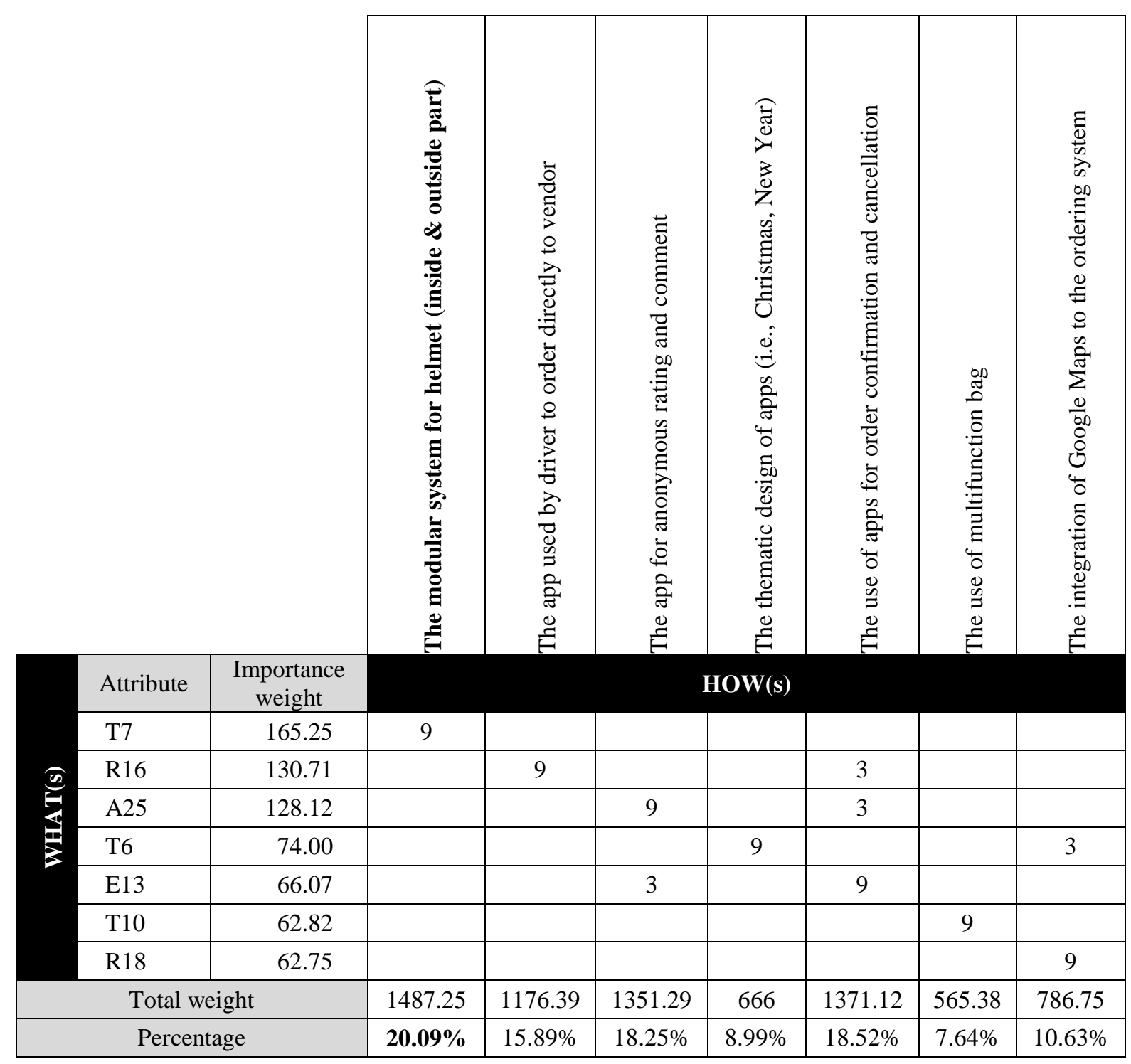

Figure 4 Simple form of HoQ for IT-based logistics services improvement

\section{DISCUSSION}

This study was carried out as an extension of previous research on KE, Kano and QFD applied in services (see Hartono et al., 2013). By looking at logistics services, this study hoped to contribute to the efficiency of logistics performance. The field of logistics services is becoming a potential niche for businesses to explore. There was a huge market growth in logistics in Indonesia in the years 2004 to 2014, and it is still becoming larger due to the growth of infrastructure and economic development. Moreover, with respect to the customer's point of view, 3PL was chosen since these kinds of services can add a great deal of value to customers and companies (Chen et al., 2015).

This study has been conducted to support the potential development of emotional-based service quality tools, and the potential needs of 3PL services. It proposes a framework of KE, Kano and QFD applied to a popular IT-based supporting logistics service in Surabaya which provides logistical services for foods, documents and passengers.

From the research findings, it has been shown that the attribute "cleanliness of helmet for customer" was most important, with a significant correlation with the Kansei terms "professional, innovative, cheap, and precise". Given limited time, effort, budget or other 
resources, the company should focus more effort on the cleanliness of helmets and supporting facilities in order to gain more customer emotional satisfaction. However, the Kansei term "helped" was the highest-rated emotion experienced by the customers. This was influenced by the performance of the attributes "web-based application interface", "appearance of food ordered", "confirmation for any cancellations", and "driver traceability". In other words, in general, the customers felt helped once they were served by the XYZ company.

It is also suggested that a modular system for the helmet (inside and outside parts) be considered. This was deemed to be the most important improvement, followed by the provision of application software to give comments and ratings anonymously, and also the use of application software for confirmation and cancellation.

\section{CONCLUSION}

This study promotes the importance of the role of human factors, especially Kansei, in influencing the efficiency and effectiveness of logistics service design and development. The integrated model of KE, Kano and QFD devised provides understanding of what should be considered and executed by the service manager or provider in improving the services offered, while focusing on prioritized solutions, given limited resources. In this study, the improvement of the helmet system, and the provision of application software for submitting comments and ratings and carrying out confirmations/cancellations were rated as high priorities.

This study was limited by a relative small sample size, and a specific IT-based logistics services. Since the proposed model is intended as a general model for the improvement of logistics services, more empirical studies are required. Moreover, the exploration of another part of the logistics services sector is needed; not only 3PL which focus on the end customer, but also on more upstream entities.

\section{ACKNOWLEDGEMENT}

This study on model development and its application to logistics services was fully supported by a research grant under the scheme of applied product with a contract number of 22/SPLit/LPPM-01/Dikti/FT/V/2017, endorsed by the Directorate of Higher Education, the Ministry of Research, Technology, and Higher Education, Republic of Indonesia. Also, it was partially supported by the Department of Industrial Engineering, University of Surabaya, Indonesia.

\section{REFERENCES}

Abras, C., Maloney-Krichmar, D., Preece, J., 2004. User-centered Design. In: Bainbridge, W. (Ed.), Encyclopedia of Human-computer Interaction. Sage Publications, Thousand Oaks

Chen, M-C., Hsu, C-L., Chang, K-C., Chou, M-C., 2015. Applying Kansei Engineering to Design Logistics Services: A Case of Home Delivery Service. International Journal of Industrial Ergonomics, Volume 48, pp. 46-59

Cook, L.S., Bowen, D.E., Chase, R.B., Dasu, S., Stewart, D.M., Tansik, D.A., 2002. Human Issues in Service Design. Journal of Operations Management, Volume 20(2), pp. 159-174

Dewi, D.S., Irfoni, A.R., Rahman, A., 2017. Kansei Engineering Approach for Designing a Self-monitoring Blood Glucose Application. International Journal of Technology, Volume 8(2), pp. 272-282

Drury, C.G., 2003. Service, Quality, and Human Factors. AI \& Society, Volume 17(2), pp. 7896

Franceschini, F., Rafele, C., 2000. Quality Evaluation in Logistic Services. International Journal of Agile Management Systems, Volume 2(1), pp. 49-53 
Hartono, M., Tan, K.C., 2011. How Kano Model Contributes to Kansei Engineering in Services. Ergonomics, Volume 54(11), pp. 987-1004

Hartono, M., 2012. Incorporating Service Quality Tools into Kansei Engineering in Services: A Case Study of Indonesian Tourists. Procedia Economics and Finance, Volume 4, pp. 201212

Hartono, M., Tan, K.C., Peacock, J.B., 2013. Applying Kansei Engineering, the Kano Model and QFD to Services. International Journal of Services, Economics and Management, Volume 5(3), pp. 256-274

Hartono, M., 2014. Incorporating Customer Emotional Needs using Kansei Engineering and Kano Model to Support Customer Relationship Management: A Case Study in Healthcare Services. In: Proceedings of Joint Asia Pacific Computer and Human Interaction and Ergofuture International Conference, October 22-25, 2014, Bali, Indonesia

Hartono, M., Raharjo, H., 2015. Exploring the Mediating Role of Affective and Cognitive Satisfaction on the Effect of Service Quality on Loyalty. Total Quality Management \& Business Excellence, Volume 26(9-10), pp. 971-985

Hartono, M., 2016a. The Extended Integrated Model of Kansei Engineering, Kano, and TRIZ Incorporating Cultural Differences into Services. International Journal of Technology, Volume 7(1), pp. 97-104

Hartono, M., 2016b. A Conceptual Integrative Model of Kansei Engineering, Kano and TRIZ Towards Sustainability in Services. In: Proceedings of $8^{\text {th }}$ Widyatama International Seminar on Sustainability, 5-8 September 2016, Bandung, Indonesia

Helander, M.G., Khalid, H.M., 2006. Affective and Pleasurable Design. In: Salvendy, G. (ed.), Handbook of Human Factors and Ergonomics. $3^{\text {rd }}$ edition, New York: Wiley Interscience, pp. 543-572

Hsu, C.L., Lin, C.S., Chen, M.C., 2011. Exploring Logistics Services Quality in Home Delivery Industry: Do Service Providers and Customers Have Different Viewpoints? Journal of Quality, Volume 18(5), pp. 439-454

Kano, N., Seraku, N., Takahashi, F., 1984. Attractive Quality and Must Be Quality. Quality, Volume 14(2), pp. 39-44

Llinares, C., Page, A.F., 2011. Kano's Model in Kansei Engineering to Evaluate Subjective Real Estate Consumer Preferences. International Journal of Industrial Ergonomics, Volume 41, pp. 233-246

Lovelock, C., 1991. Services Marketing. Prentice-Hall, Englewood Cliffs, NJ

Nagamachi, M., 1995. Kansei Engineering: A New Ergonomic Consumer-oriented Technology for Product Development. International Journal of Industrial Ergonomics, Volume 15, pp. $3-11$

Nagamachi, M., Lokman, A.M., 2011. Innovations of Kansei Engineering. Boca Raton: CRC Press

Nishino, T., Nagamachi, M., Ishihara, K., Ishihara, S., Ichitsubo, M., Komatsu, K., 1999. Internet Kansei Engineering System with Basic Kansei Database and Genetic Algorithm. In: Proceedings of TQM and Human Factors (Linkoping, Sweden: Centre for Studies of Humans, Technology and Organization), pp. 367-372

Norman, D.A., 2004. Emotional Design: Why Do We Love (or Hate) Everyday Things. New York: Basic Books

Parasuraman, A., Berry, L.L., Zeithaml, V.A., 1988. SERVQUAL: A Multiple-item Scale for Measuring Consumer Perceptions of Service Quality. Journal of Retailing, Volume 64, pp. $12-40$

Rasamoelina, F., Bouchard, C., Aoussat, A., 2013. Towards a Kansei-based User Modeling Methodology for Eco-design. International Journal of Affective Engineering, Volume 12(2), pp. 337-348 
Schütte, S., 2005. Engineering Emotional Values in Product Design. Kansei Engineering in Development. Thesis. Linkoping University, Linkoping

Stefano, N.M., Casarotto, F.N., Barichello, R., Sohn, A.P., 2015. A Fuzzy SERVQUAL Based Method for Evaluated of Service Quality in the Hotel Industry. Procedia CIRP, Volume 30, pp. 433-438

Tan, K.C., Pawitra, A.T., 2001. Integrating SERVQUAL and Kano's Model into QFD for Service Excellent Development. Managing Service Quality, Volume 11, pp. 418-430

Vargo, S.L., Lusch, R.F., 2004. The Four Service Marketing Myths-remnants of Goods-based Manufacturing Model. Journal of Service Research, Volume 6(4), pp. 324-335

Wong, A., 2004. The Role of Emotional Satisfaction in Service Encounters. Managing Service Quality, Volume 14(5), pp. 365-376

Yogasara, T., Valentino, J., 2017. Realizing the Indonesian National Car: The Design of the $4 \times 2$ Wheel Drive Passenger Car Exterior using the Kansei Engineering Type 1. International Journal of Technology, Volume 8(2), pp. 338-351 